\title{
Study on the Effects of Economic Growth to Farmland Conversion in China
}

\author{
Li Zhang1, Yonghui Wang ${ }^{2}$ \\ ${ }^{1}$ School of Economics and Management Engineering, Beijing University of Civil Engineer and Architecture, \\ Beijing, China \\ ${ }^{2}$ The Center for Housing Industrialization, Ministry of Housing and Urban-Rural Development of the People's \\ Republic of China, Beijing, China \\ Email: zhangli qhd@126.com, wyh@chinahouse.gov.cn
}

Received May 2014

\begin{abstract}
With the rapid development of Chinese economy and acceleration of urbanization, farmland conversion trend is inevitable. In order to analyze the effects of economic growth to farmland conversion in China, the author chooses the data of building occupied land area, per capita gross domestic product, industrial structure, input-output ratio, consumption growth rate and urban and rural income ratio and establishes a set of regression model with the aid of SPSS software. From the result of the model analysis, we can conclude that the impact of economic growth on farmland conversion appears the inverted $U$ curve. The rise of third industry and urban residents' income will stimulate the demand for farmland.
\end{abstract}

\section{Keywords}

Economic Growth, Farmland Conversion, Econometric Analysis

\section{Introduction}

Farmland conversion means to change farmland use and become the construction land of city residential, industrial, service industry and infrastructure. With the rapid development of Chinese economy and acceleration of urbanization, farmland conversion trend is inevitable. From 2004 to 2011, the area of land expropriation increased from 196,000 hectares to 569,000 hectares, average annual growth of about 15\%. Farmland conversion improves the living level of millions of farmers, promotes the rapid development of industry, and makes a large contribution to the economic development. But with the increase of population, the per capita arable land has been from 1.59 acres in 1996 dropped to 1.35 acres in 2012, decreased by 15\%. The contradiction between population and land became more and more glaring. In the new era of global sustainable development, protection of cultivated land has become the primary task for the sustainable development of China's land. Therefore, it is necessary to strengthen the quantitative research on the problems of farmland conversion, find out the driving force and influence factors of farmland conversion and set up the new mechanism of farmland conversion. 


\section{Select the Economic Growth Index}

Since the reform and open policy in China, each economic indicator rate of rise has occupied the world leader, economic output and economic quality ad the huge promotion. Economic growth emphasizes the raise of total economic output, the expansion of economic scale, the growth of production efficiency, the increase of wealth and the improvement of living standards. To measure the economic growth indicators include the index of economic output and the index of economic structure. According to the study purpose and data characteristics, this paper selects the following indicators to analyze the driving effects of economic growth to farmland conversion through establishing econometric model.

\subsection{Per Capita Gross Domestic Product}

Gross domestic product is an aggregative indicator which reflects the level of socioeconomic development of a country or a region. The per capita GDP reflects a nation's economic strength. This paper selects per capita GDP (X) to analyze the impact of Chinese economy to farmland conversion. In order to exclude the impact of inflation, we convert it to 1978 as the base period of constant prices.

\subsection{Industrial Structure}

In China, three industry contribution rate of GDP is from 41.6:41:17.3 in 1990 to 5.7:48.7:45.6 in 2012. The pulling effect of first industry to GDP decreased gradually, and the pulling effect of third industry to GDP fast rise. At present, second and third industries have become the core strength in Chinese economic growth. Therefore, this paper selects the proportion of second industrial added value to GDP $\left(\mathrm{C}_{1}\right)$ and the proportion of the third industrial added value to GDP $\left(\mathrm{C}_{2}\right)$, to analyze the influence of industrial structure to farmland conversion.

\subsection{Input-Output Ratio}

Input-output level is an important index to reflect the development of a dynamic economy, used to measure the economic benefit of investment. This paper selects the proportion of fixed-asset investment to GDP $\left(\mathrm{C}_{3}\right)$ to analyze the influence of input-output level to farmland conversion.

\subsection{Consumption Growth Rate}

The consumption level is the scale and level of domestic consumption and services. This paper selects the growth rate of total retail sales of consumer goods $\left(\mathrm{C}_{4}\right)$ to analyze the influence of consumption level to farmland conversion.

\subsection{Urban and Rural Income Ratio}

With the rapid economic growth, the income level of residents has been greatly improved, and the urban-rural income gap is expanding. This paper selects the ratio of urban residents' disposable income to rural households' net income $\left(C_{5}\right)$ to analyze the influence of urban and rural income level to farmland conversion.

\section{Econometric Analysis of Economic Growth to Farmland Conversion}

\subsection{Data Collection}

This article collected building occupied land area and various economic indicators from the "China Land Resources Statistics Yearbook” and “Chinese Statistical Yearbook” (see Table 1).

\subsection{Model Construction}

According to the classic environmental Kuznets curve, refers to the income and trade model and income, institutional and policy model, this paper constructs the following multiple model set, as in [1]-[6]:

$$
\begin{gathered}
\operatorname{Ln} Y=\alpha+\beta_{1} \operatorname{Ln} X+\beta_{2}(\operatorname{Ln} X)^{2}+\beta_{3}(\operatorname{Ln} X)^{3}+\varepsilon \\
\operatorname{Ln} Y=\alpha+\beta_{1} \operatorname{Ln} X+\beta_{2}(\operatorname{Ln} X)^{2}+\beta_{3}(\operatorname{Ln} X)^{3}+\beta_{4} C_{i} \operatorname{Ln} X+\varepsilon
\end{gathered}
$$


Table 1. Basic data of economic growth and farmland conversion (from 1999 to 2011).

\begin{tabular}{cccccccc}
\hline Year & $\begin{array}{c}\text { Farmland } \\
\text { conversion area } \\
\text { (Hectare) }\end{array}$ & $\begin{array}{c}\text { Per capita } \\
\text { GDP } \\
\text { (Yuan) }\end{array}$ & $\begin{array}{c}\text { The rate of second } \\
\text { industry to GDP } \\
(\%)\end{array}$ & $\begin{array}{c}\text { The rate of third } \\
\text { industry to GDP } \\
(\%)\end{array}$ & $\begin{array}{c}\text { Input output } \\
\text { ratio } \\
(\%)\end{array}$ & $\begin{array}{c}\text { Consumption } \\
\text { growth rate } \\
(\%)\end{array}$ & $\begin{array}{c}\text { Urban and } \\
\text { rural income ratio } \\
(\%)\end{array}$ \\
\hline 1999 & 60355.59 & 2039.20 & 45.76 & 37.77 & 33.29 & 6.80 & 2.65 \\
2000 & 93583.74 & 2193.98 & 46.21 & 36.23 & 33.18 & 9.70 & 2.79 \\
2001 & 110180.18 & 2358.67 & 47.54 & 34.17 & 33.94 & 10.10 & 2.90 \\
2002 & 137836.95 & 2555.77 & 47.54 & 32.77 & 36.15 & 11.80 & 3.11 \\
2003 & 275481.34 & 2794.80 & 47.18 & 32.86 & 40.91 & 9.10 & 3.23 \\
2004 & 167400.30 & 3058.23 & 46.57 & 33.57 & 44.08 & 13.30 & 3.21 \\
2005 & 252958.39 & 3384.18 & 46.57 & 33.72 & 48.00 & 14.88 & 3.22 \\
2006 & 288052.26 & 3792.09 & 43.45 & 34.76 & 50.85 & 15.79 & 3.28 \\
2007 & 274365.52 & 4306.37 & 41.79 & 33.69 & 51.66 & 18.23 & 3.33 \\
2008 & 270185.75 & 4697.13 & 41.34 & 31.54 & 55.03 & 22.72 & 3.31 \\
2009 & 413793.10 & 5104.67 & 42.83 & 32.06 & 65.88 & 15.54 & 3.33 \\
2010 & 374934.98 & 5610.56 & 43.79 & 30.51 & 62.68 & 18.33 & 3.33 \\
2011 & 410538.55 & 6103.11 & 43.55 & 29.64 & 65.84 & 17.15 & 3.23 \\
\hline
\end{tabular}

$$
\begin{gathered}
\operatorname{Ln} Y=\alpha+\beta_{1} \operatorname{Ln} X+\beta_{2}(\operatorname{Ln} X)^{2}+\beta_{4} C_{i} \operatorname{Ln} X+\beta_{5} C_{i}+\varepsilon \\
\operatorname{Ln} Y=\alpha+\beta_{1} \operatorname{Ln} X+\beta_{3}(\operatorname{Ln} X)^{3}+\beta_{4} C_{i} \operatorname{Ln} X+\beta_{5} C_{i}+\varepsilon \\
\operatorname{Ln} Y=\alpha+\beta_{1} \operatorname{Ln} X+\beta_{4} C_{i} \operatorname{Ln} X+\beta_{5} C_{i}+\varepsilon
\end{gathered}
$$

With the aid of SPSS software, this paper establishes a set of regression model. Through goodness of fit test, variable significant test, equation significant test, heteroskedasticity test, serial correlation test, multicollinearity test and so on, we choose the optimal model as follows:

1) Model of per capita GDP and farmland conversion area

Model I:

$$
\begin{gathered}
\operatorname{Ln} Y=-102.919+26.767 \operatorname{Ln} X-1.548(\operatorname{Ln} X)^{2} \\
(-2.72)(2.884)(-2.723) \\
\bar{R}^{2}=0.881 F=45.442 D W=2.313
\end{gathered}
$$

2) Model of industrial structure and farmland conversion area

Model II:

$$
\begin{gathered}
\operatorname{Ln} Y=-126.535+32.972 \operatorname{Ln} X-1.885(\operatorname{Ln} X)^{2}-0.012 C_{1} \operatorname{Ln} X \\
(-2.87)(2.99)(-2.883) \quad(-2.034) \\
\bar{R}^{2}=0.881 F=30.858 \quad D W=2.81
\end{gathered}
$$

Model III:

$$
\begin{gathered}
\operatorname{Ln} Y=-96.996+25.159 \operatorname{Ln} X-1.527(\operatorname{Ln} X)^{2}+0.017 C_{2} \operatorname{Ln} X \\
(-2.903)(3.067)(-3.055)
\end{gathered}
$$




$$
\bar{R}^{2}=0.908 \quad F=40.47 \quad D W=2.701
$$

3) Model of input-output ratio and farmland conversion area Model IV:

$$
\begin{gathered}
\operatorname{Ln} Y=-12.094+2.82 \operatorname{Ln} X+0.426 C_{3}-0.048 C_{3} \operatorname{Ln} X \\
(-1.381)(2.403)(2.350) \quad(-2.337) \\
\bar{R}^{2}=0.857 F=25.067 \quad D W=1.927
\end{gathered}
$$

4) Model of consumption growth rate and farmland conversion area

Model V:

$$
\begin{gathered}
\operatorname{Ln} Y=-150.280+37.789 \operatorname{Ln} X-2.171(\operatorname{LnX})^{2}-0.008 C_{4} \operatorname{Ln} X \\
\quad(-5.01)(5.193)(-4.946) \quad(-3.373) \\
\bar{R}^{2}=0.942 \quad F=65.523 \quad D W=2.725
\end{gathered}
$$

5) Model of urban and rural income ratio Model VI:

$$
\begin{gathered}
\operatorname{Ln} Y=6.33+0.027(\operatorname{Ln} X)^{2}+0.161 C_{5} \operatorname{Ln} X \\
(10.579)(3.609)(2.355) \\
\bar{R}^{2}=0.905 \quad F=58.415 \quad D W=2.447
\end{gathered}
$$

\section{Conclusions}

\subsection{Effect of Total Economic Output to Farmland Conversion}

From Model, we can find that the impact of economic growth on farmland conversion appeared the inverted U curve. On early stage of economic growth, farmland conversion speed along with the improvement of per capita GDP rapid increase. When economic growth reaches a certain level, people pay more and more attention to the protection of land resources, farmland conversion rate will be decreased. According to the principle of extreme values of derivative, when per capita GDP is 5500 Yuan, farmland conversion growth rate reached a maximum value. So after 2011, protection of land resources will be gradually strengthen, farmland conversion speed will be gradually slow down, the quality of farmland conversion will be optimized. Finally, we will realize the sustainable development of society, economy and environment.

\subsection{Effect of Economic Structure to Farmland Conversion}

In order to analyze the impact of individual variables on land resources loss under fixing other control variables, we calculate a derivative of logarithm of farmland conversion regression equation.

The formula is:

$$
\frac{\partial \operatorname{Ln} Y}{\partial C_{i}}
$$

We can calculate the marginal change of farmland conversion (see Table 2).

1) Effect of industrial structure to farmland conversion

To some extent, up grading industrialization level will alleviate the speed of farmland conversion growth. At first, the rise of third industry will stimulate the demand for farmland. In the future, when the development of third industry entered the mature stage, it will gradually reduce the demand for farmland.

2) Effect of input-output ratio to farmland conversion

Although from 1999 to 2011, fixed asset investment maintained rapid growth, because of investment structure optimization, it gradually reduces the demand for farmland.

3) Effect of consumption growth rate to farmland conversion 
Table 2. The marginal change of farmland conversion.

\begin{tabular}{|c|c|c|c|c|c|}
\hline \multirow{2}{*}{ Year } & $\begin{array}{l}\text { The rate of second } \\
\text { industry to GDP }\end{array}$ & $\begin{array}{l}\text { The rate of third industry to } \\
\text { GDP }\end{array}$ & $\begin{array}{c}\text { Input output } \\
\text { ratio }\end{array}$ & $\begin{array}{l}\text { Consumption growth } \\
\text { rate }\end{array}$ & $\begin{array}{c}\text { Urban and rural income } \\
\text { ratio }\end{array}$ \\
\hline & $\mathrm{C}_{1}$ & $\mathrm{C}_{2}$ & $\mathrm{C}_{3}$ & $\mathrm{C}_{4}$ & $\mathrm{C}_{5}$ \\
\hline-0.09144 & & 0.129545 & 0.060225 & -0.06096 & 1.22687 \\
\hline-0.09232 & & 0.130789 & 0.056713 & -0.06155 & 1.238649 \\
\hline-0.09319 & & 0.13202 & 0.053239 & -0.06213 & 1.250302 \\
\hline-0.09415 & & 0.133384 & 0.049386 & -0.06277 & 1.263224 \\
\hline-0.09523 & & 0.134904 & 0.045095 & -0.06348 & 1.277618 \\
\hline-0.09631 & & 0.136435 & 0.040771 & -0.0642 & 1.29212 \\
\hline-0.09752 & & 0.138157 & 0.035910 & -0.06501 & 1.308426 \\
\hline-0.09889 & & 0.140091 & 0.030447 & -0.06593 & 1.326748 \\
\hline-0.10041 & & 0.142253 & 0.024343 & -0.06694 & 1.347224 \\
\hline-0.10146 & & 0.14373 & 0.020174 & -0.06764 & 1.361208 \\
\hline-0.10245 & & 0.145144 & 0.016180 & -0.0683 & 1.374604 \\
\hline-0.10359 & & 0.146751 & 0.011644 & -0.06906 & 1.389817 \\
\hline-0.1046 & & 0.148181 & 0.007605 & -0.06973 & 1.403365 \\
\hline
\end{tabular}

The effect of consumption growth rate to farmland conversion is very little. With the development of economy, people's actual consumption level has been greatly improved, consumption structure has also changed, but from 1999 to 2011, the improvement of people's consumption level did not increase the demand for farmland.

4) Effect of urban and rural income ratio to farmland conversion

Because the income of urban residents increases more and more quickly, there is a great income gap between urban residents and rural residents. The increasing income of urban residents stimulates the demand for farmland, so more and more farmland change into construction land.

\section{References}

[1] Harbangh, W.T., Levinson, A. and Wilson, D.M. (1999) Reexamining the Empirical Evidence for Environmental Kuznets Curve. Environmental Pollution, 2, 33.

[2] Cropper M. and Griffiths, C. (1994) The Interaction of Population Growth and Environmental Quality. American Economic Review, 84, 250-254.

[3] Suri, V. and Chapman, D. (1998) Economic Growth, Trade and Energy: Implications for the Environmental Kuznets Curve. Ecological Economics, 25, 195-208. http://dx.doi.org/10.1016/S0921-8009(97)00180-8

[4] Torras, M. and Boyce, J. (1998) Income, Inequality, and Pollution: A Reassessment of the Environmental Kuznets Curve. Ecological Economics, 25, 147-160. http://dx.doi.org/10.1016/S0921-8009(97)00177-8

[5] Madhusudan, B. and Michael, H. (2001) Institutions and the Environmental Kuznets Curve for Deforestation: A Cross-Country Analysis for Latin America. Africa and Asia World Development, 29, 995-1010.

[6] He, B.B., Liu, Y.Z. and Zhang, J. (2008) Measurement and Analysis of the Relationships between Farm Land Conversion and Economic Growth in China. Journal of Arid Land Resources and Environment, 6, 21-26. 